

\section{DISCLAIMER}

This report was prepared as an account of work sponsored by an agency of the United States Government. Neither the United States Government nor any agency Thereof, nor any of their employees, makes any warranty, express or implied, or assumes any legal liability or responsibility for the accuracy, completeness, or usefulness of any information, apparatus, product, or process disclosed, or represents that its use would not infringe privately owned rights. Reference herein to any specific commercial product, process, or service by trade name, trademark, manufacturer, or otherwise does not necessarily constitute or imply its endorsement, recommendation, or favoring by the United States Government or any agency thereof. The views and opinions of authors expressed herein do not necessarily state or reflect those of the United States Government or any agency thereof. 


\section{DISCLAIMER}

Portions of this document may be illegible in electronic image products. Images are produced from the best available original document. 
Printed in the United States of America. Available from National Technical Information Service

U.S. Department of Commerce

5285 Port Royal Road, Springfield, Virginia 22161

Price: Printed Copy $\$ 4.00$; Microfiche $\$ 3.00$

This report was prepared as an account of work sponsored by an agency of the United States Government. Neither the United States Government nor any agency thereof, nor any of their employees, nor any of their contractors, subcontractors, or their employees, makes any warranty, express or implied, nor assumes any legal liability or responsibility for any third party's use or the results of such use of any information, apparatus, product or process disclosed in this report, nor represents that its use by such third party would not infringe privately owned rights. 
Date of Issue: December 9, 1977

Distribution Category: UC-25

\title{
INVESTIGATION OF A LITHIUM ELECTROLYTIC CELL FAILURE
}

\author{
R. C. Anderson
}

Motallurgy Department.

Y-12 Development Division

This report was prepared as an account of work
sponsored by the United States (invemment. Neither the
United States not the United States Department of
Fnergy. nnr any nf their imploypoe, not any of their
contractors, subcontractors, or their employees, makes
any warranty, express or implied, or astumes any logal
liability or responsibility for the accuracy, completeness
or usefulness of any information, apparatus, product or
process disclosed, or represents that its use would not
infringe privately owned rights.

Oak Ridge Y-12 Plant

P. O. Box Y, Oak Ridge, Tennessee 37830

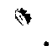

Prepared for the US Energy Research and Development Administration

Under US Government Contract W.7405-eng-26 


\begin{abstract}
Electrolytic cells, used to produce lithium metal, fail after approximately three years in service. A metallurgical investigation revealed that molten lithium at $440^{\circ} \mathrm{C}$ was dissolving the carbon in the cementite which is a constituent in the steel plate from which the cell is fabricated.
\end{abstract}


CONTENTS

SUMMARY

4

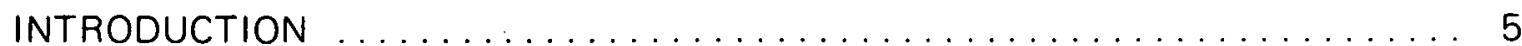

FAILURE OF A LITHIUM ELECTROLYTIC CELL $\ldots \ldots \ldots \ldots \ldots \ldots \ldots$

Experimental Work ................................... 6

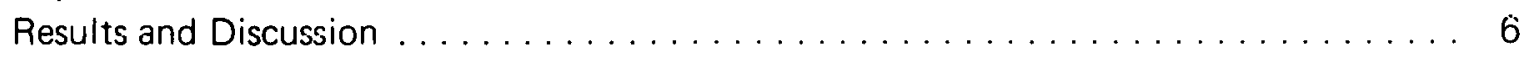

Conclusions and Recommendations $\ldots \ldots \ldots \ldots \ldots \ldots \ldots \ldots \ldots \ldots \ldots \ldots$

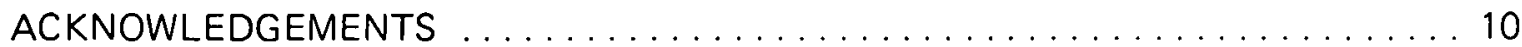




\section{SUMMARY}

Molten lithium, at $4400 \mathrm{C}$, dissolves the carbon in the cementite which is a constitutent in. the steel plate of the lithium cell. A tunneling type of attack by the lithium into the lamellar pearlite is the mode of corrosion.

Using a low-carbon iron or steel, or spheroidizing the cementite in the cell after fabrication, should reduce the corrosive effect of molten lithium on the cell. 


\section{INTRODUCTION}

Electrolytic cells are used in the Oak Ridge $Y-12$ Plant ${ }^{(a)}$ to produce lithium metal from a molten lithium chloride/potassium chloride $(\mathrm{LiCl} / \mathrm{KCl})$ salt eutectic. Cells frequently develop leaks after approximately three years of continuous service. If the service life of the cell could be increased, a considerable saving in downtime and cost of a new cell would ensue. The objective of this investigation was to determine the mechanism of cell.failure and methods that would provide failure retardation.

(a) Operated by the Union Carbide Corporation's Nuclear Division for the Department of Energy. 


\section{FAILURE OF A LITHIUM ELECTROLYTIC CELL}

\section{EXPERIMENTAL WORK}

Lithium electrolytic cells are fabricated from 19-mm (3/4-in)-thick ASTM. A285 Grade A steel (boiler plate). The tank is hot sprayed with stainless steel on the outside surface to protect it during heating by exterior gas burners. The salt temperature is $440^{\circ} \mathrm{C}$.

Analytical methods used to determine cell failure included: (1) chemical analysis of a cross section of the cell in the area of a leak, (2) metallographic examination of as-received and failed steel plate, (3) scanning electron microscopy (SEM) of fracture surfaces consisting of a portion of the crack which had penetrated the cell wall and one produced in the laboratory by an overload that extended an existing crack, and (4) ion microprobe analysis of the attacked areas in the cross section of the plate.

\section{RESULTS AND DISCUSSION}

Chemical analysis of the as-received and failed plate is given in Table 1. The most pertinent aspect of the chemical analysis is the decrease in carbon content of the steel (from approximately $1600 \mathrm{ppm}$ in the as-received plate to $12 \mathrm{ppm}$ in the failed plate).
Table 1

CHEMICAL ANALYSIS OF ASTM A285 GRADE A PLATE

\begin{tabular}{lcc}
\hline & \multicolumn{2}{c}{ Concentration (ppm) } \\
\cline { 2 - 3 } Element & As-Received Plate & $\begin{array}{c}\text { After Failure } \\
\text { in a Cell }\end{array}$ \\
\hline Carbon & $1500-1700$ & $11-13$ \\
Oxygen & $1500(\max )$ & 899 \\
Nitrogen & NA(1) & 4 \\
\hline
\end{tabular}

(1) Not available.

Dark areas at the ferrite grain boundaries in Figure 1 are pearlite which is made up of alternate layers of cementite $\left(\mathrm{Fe}_{3} \mathrm{C}\right.$ ) and ferrite ( $\alpha$ iron). In steel plate that has been in service as a lithium cell, the pearlitic areas are gray in appearance and more angular, as seen in Figure 2.

SEM revealed that failure was caused by a type of intergranular corrosion which, in turn, produced cracks that propagated from the inside and progressed toward the outside wall of the vessel. It was observed that some elements and/or compounds penetrated the grain boundaries far beyond the crack tips and weakened the metal. The gas flame did erode some of the outside surface but did not directly contribute to the failure.

Figure 3 shows the tunneling type of attack that was present in the plate; Figure 4 shows the white corrosion product observed on fracture surfaces.

Using ion microprobe analysis, lithium, oxygen, chlorine, and carbon were found most strongly concentrated in the gray areas (Figure 2). Hydrogen and fluorine were also observed in these areas. The presence of hydrogen suggests the presence of hydroxide or adsorbed or hydrated water which may have formed during exposure to the atmosphere. 


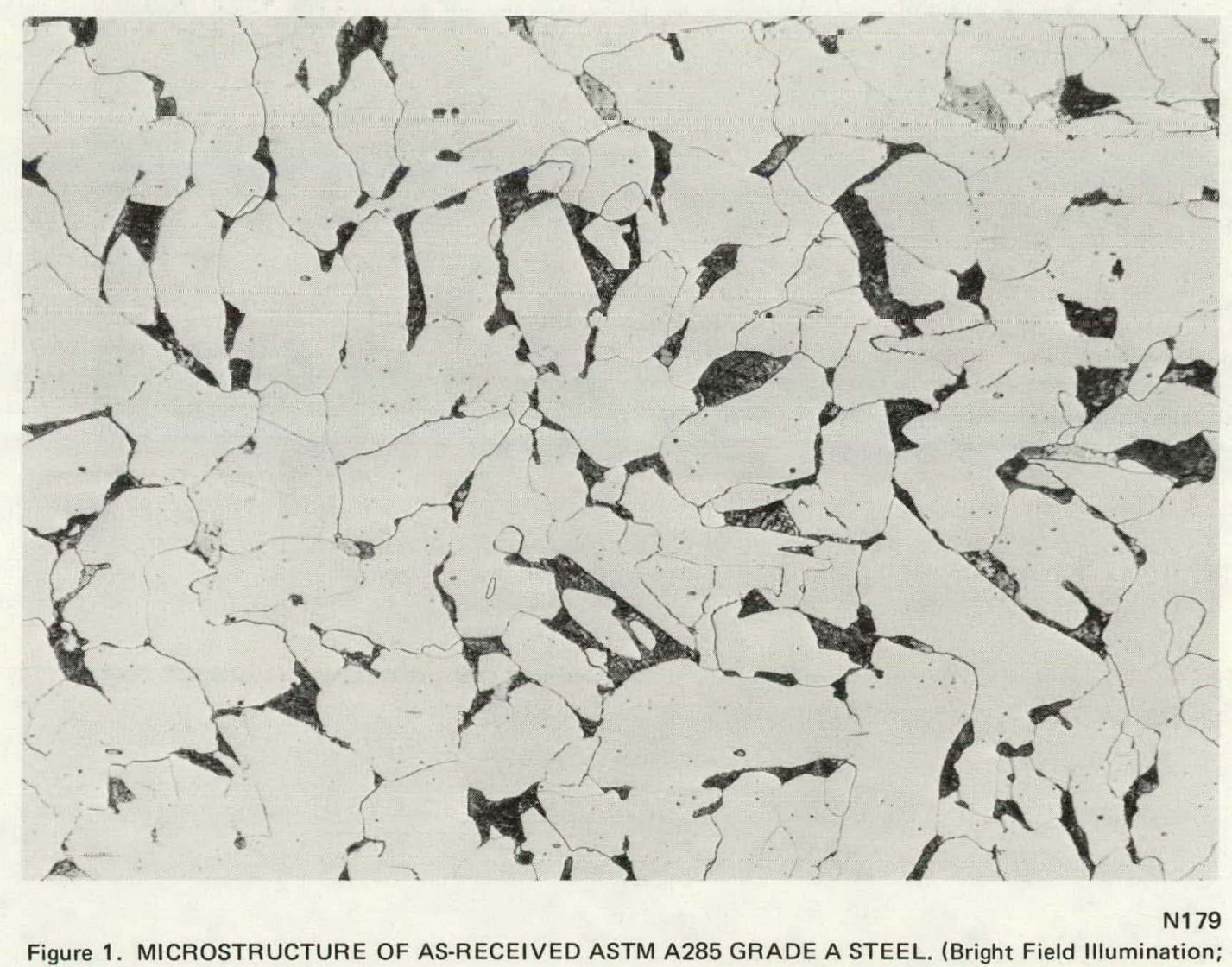

Figure 1.
250x)

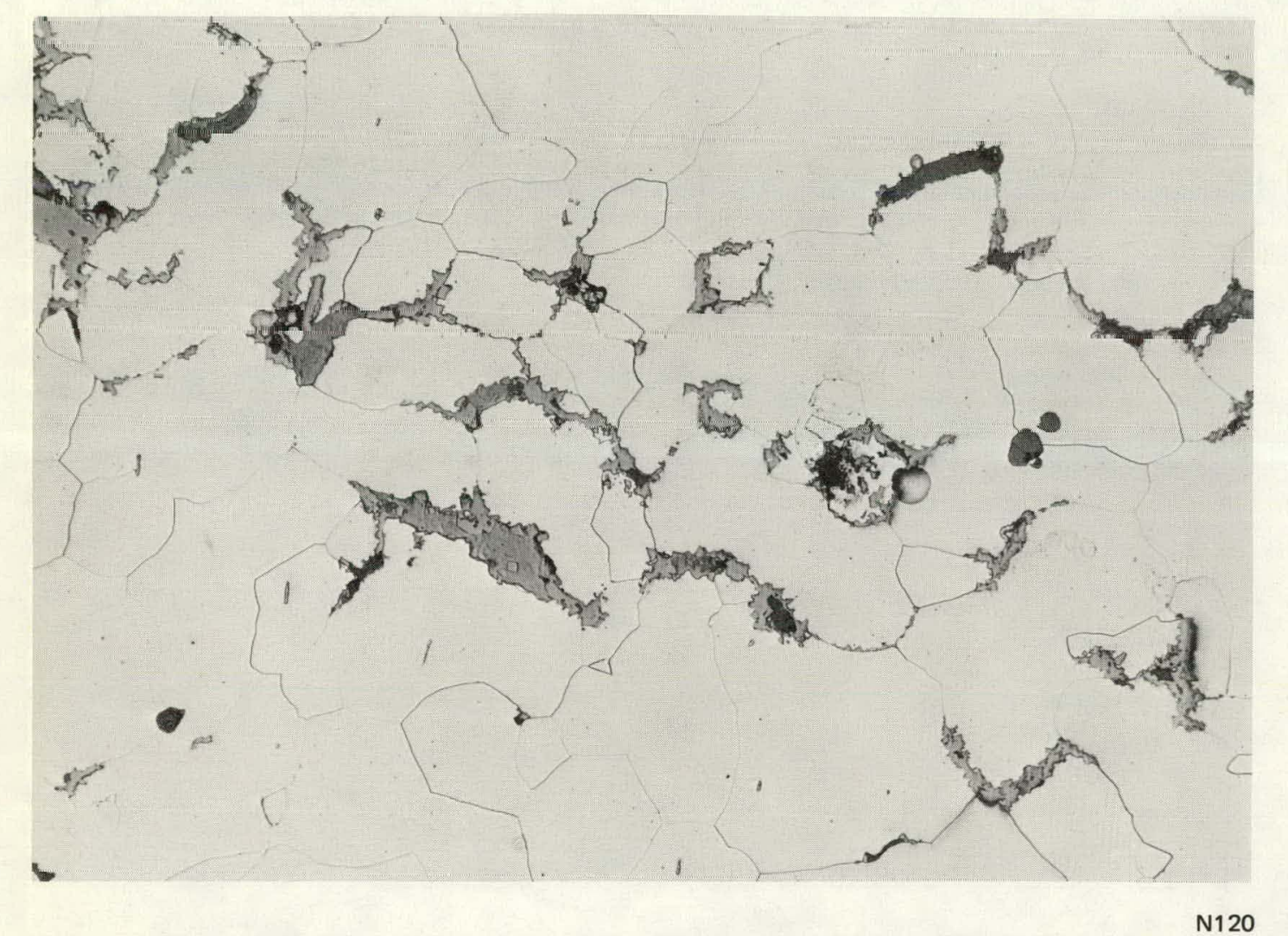

N120
Figure 2. MICROSTRUCTURE OF ASTM A285 GRADE A STEEL AFTER THREE YEARS OF SERVICE IN
A LITHIUM ELECTROLYTIC CELL. (Brigight Field Illumination; 250X)

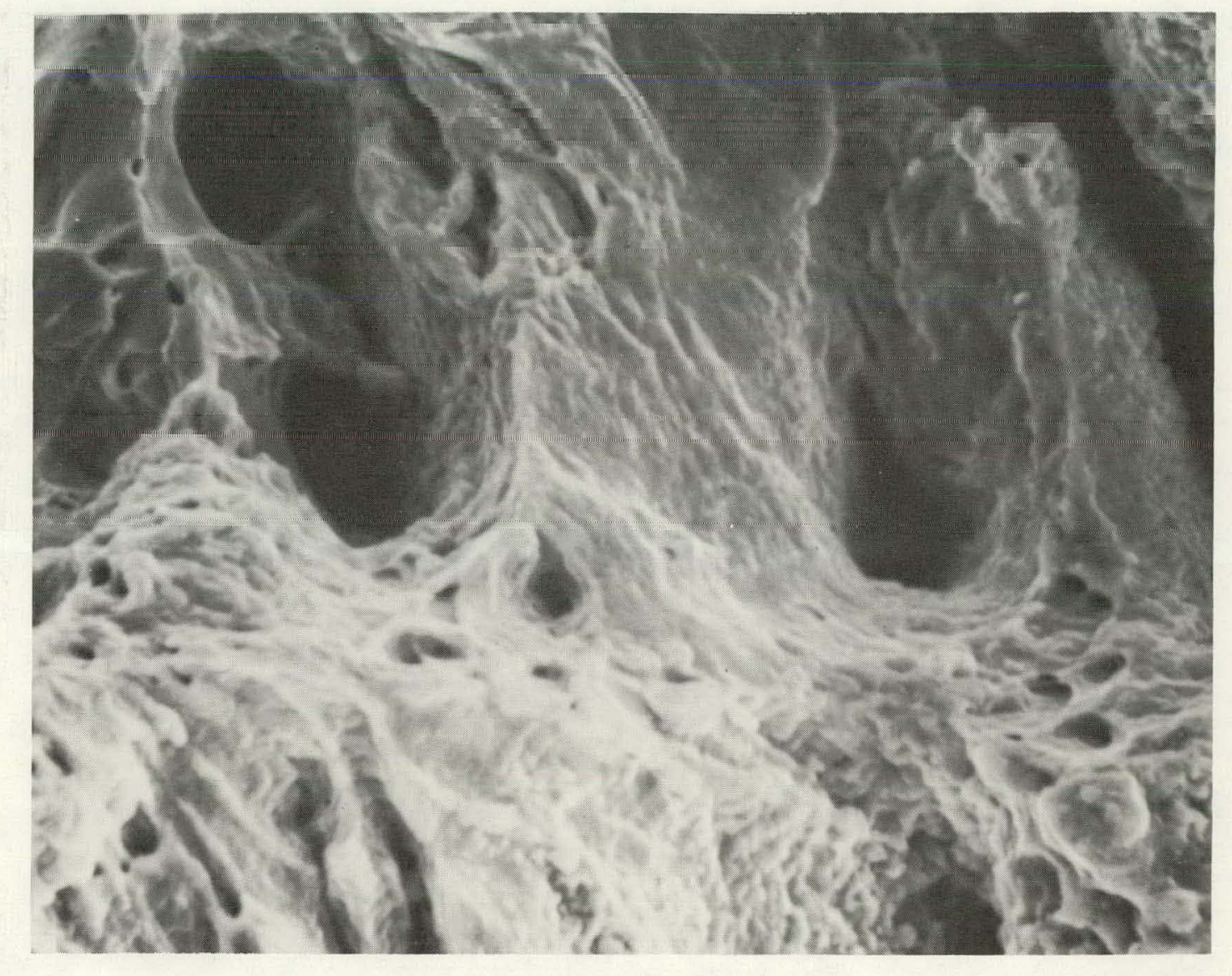

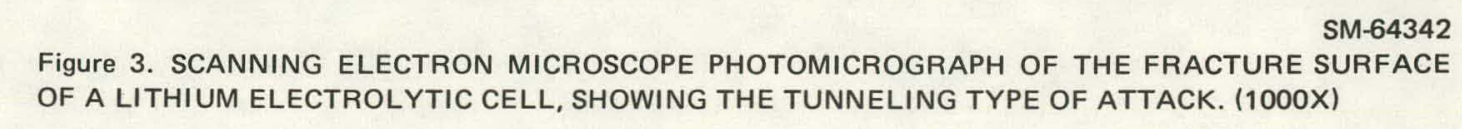




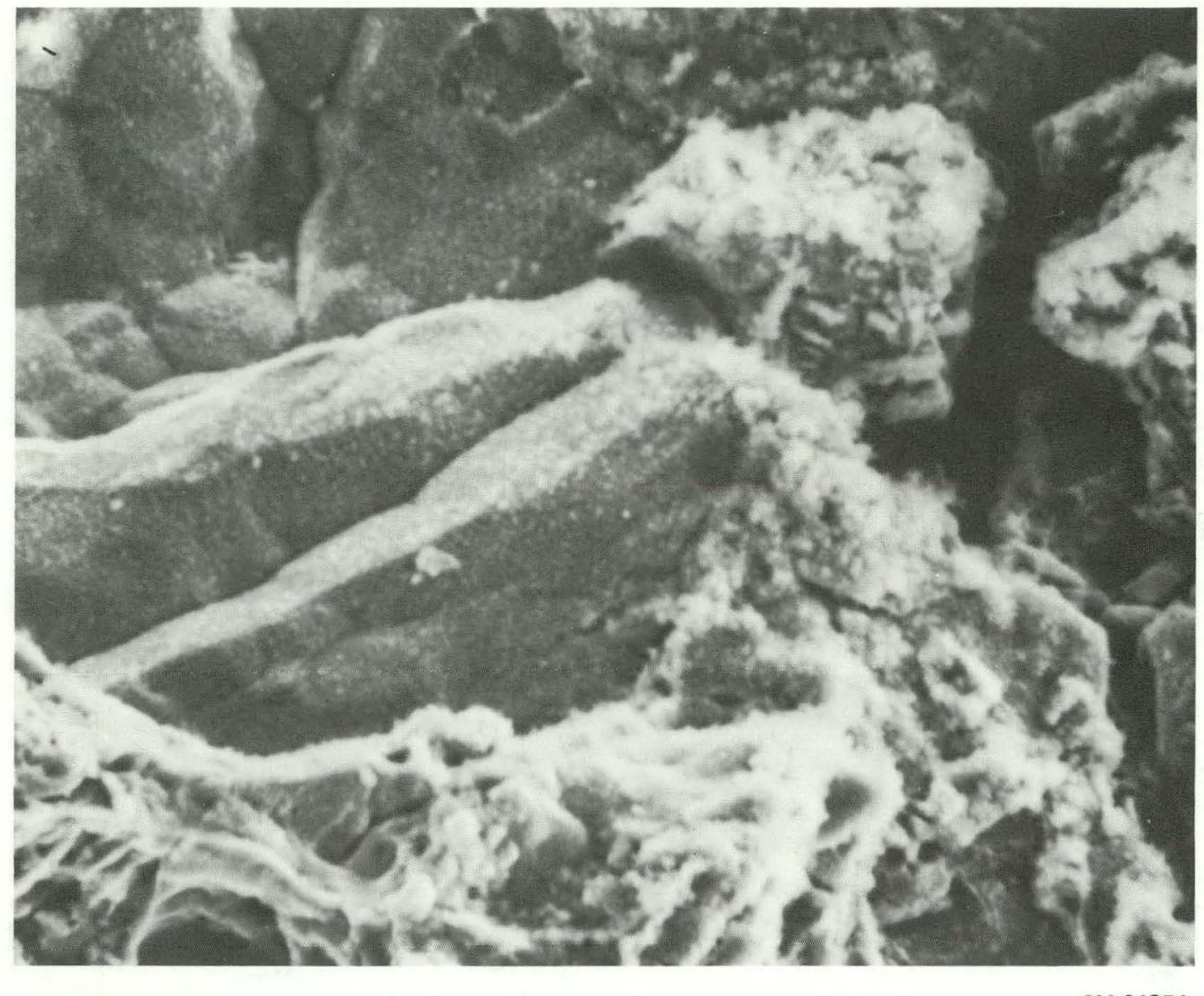

Figure 4. SCANNING ELECTRON MICROSCOPE PHOTOMICROGRAPH OF THE FRACTURE SURFACE OF A LITHIUM ELECTROLYTIC CELL, SHOWING CORROSION PRODUCT. (1000X)

Lithium and chlorine are major constituents, and fluorine is an impurity in the molten salt. Carbon is a constituent of the steel plate.

Ferrous alloys are resistant to lithium at temperatures to $400^{\circ} \mathrm{C}$. It is postulated that decarburization at temperatures to $7230 \mathrm{C}$ occurs as follows:

$$
2 \mathrm{Fe}_{3} \mathrm{C}+2 \mathrm{Li} \stackrel{\triangle}{\longrightarrow} \mathrm{Li}_{2} \mathrm{C}_{2}+6 \mathrm{Fe}
$$

The $\mathrm{Li}_{2} \mathrm{C}_{2}$ is dissolved in the lithium, causing a volume increase and producing stresses and differential strains which affect the penetration of the lithium in the steel. (b) Higher carbon steels are particularly susceptible to decarburization attack. Carbon is primarily present in the cementite, a constituent in the steel plate. Ferrite has a low solubility for carbon and does not appear to bc attacked by molten lithium.

(b) Berry, W. E.; Corrosion in Nuclear Applications, p 291; John Wiley and Sons, Inc, New York (1971). 


\section{CONCLUSIONS AND RECOMMENDATIONS}

Lithium, at $400^{\circ} \mathrm{C}$, attacks the steel by dissolving the carbon from the cementite phase. The following recommendations are made in their decreasing order of merit:

1. $\mathrm{BOH}$ ingot iron $(\mathrm{c})$ plate and welding rod, with 100 to $150 \mathrm{ppm}$ carbon should be used to fabricate the lithium cells.

2. A selected heat of rimmed steel with a maximum carbon content of $500 \mathrm{ppm}$ should also be used.

3. After fabrication of a lithium cell, using ASTM A285 Grade A steel, a spheroidizing treatment at 685 to $700^{\circ} \mathrm{C}$ would change the geometry of the cementite phase from a lamellar to a spheroidal structure and thus disrupt the tunneling type of attack in the pearlite areas.

(c) Moore, G. A.; "Preparation of Metallic Iron of High Purity", Trans AIME, 197, p 1443 (1953). 


\section{ACKNOWLEDGEMENTS}

The author, wishes to thank R. K. Bennett and S. S. Cristy of the Microanalysis Section of the Instrumentation and Characterization Department for performing the scanning electron microscopy and ion microprobe examinations of plate from the failed electrolytic cell. 


\section{Distribution}

\section{Department of Energy - Oak Ridge}

Hickman, H. D.

Leed, R. E.

Zachry, D. S., Jr

Oak Ridge Gaseous Diffusion Plant

Stief, S. S.

Wilcox. W. J., Jr

\section{Oak Ridge Y-12 Plant}

Alvey, H. E.

Anderson, R. C. (10)

Bernarider, N. K.

Bostock, D. J.

Brotherton, R. P.

Burditt, R. B.

DeVan, J. H.

Dodson, W. H.

Duggan, H. G.

Fraser, R. J.

Gritzner, V. B.

Haeusler, K. R.

Jackson, V. C.

Jones, F. W.

Kahl, K. G.

Keith, A.

Kite, H. T.

Koger, J.W.

Martin, W. R./Googin, J. M.

Mason, D. L./Schreyer, J. M.

Mills, J. M., Jr

Phillips, L. R.

Rhew, J. E.

Smlth, H. F., Ji .

Smith, R. D.

Stoner, $\mathrm{H}$. $\mathrm{H}$.

Tewes, W. E.

Thompson, W. H., Jr

Tilson, F. V.

$Y-12$ Central Files (master copy)

$Y-12$ Central Files (route copy)

$Y-12$ Central Files ( $Y$-12RC)

$Y-12$ Cential Files (5)
Paducah Gaseous Diffusion Plant

Bewley, H. D. 